\title{
The Effects of Cost and Asset Retrenchment on Firm Performance: The Overlooked Role of a Firm's Competitive Environment
}

\author{
J.L. Morrow Jr. \\ Division of Business and Graduate Programs, Birmingham-Southern College, \\ 900 Arkadelphia Road, Box 549052, Birmingham, AL 35254, USA \\ Richard A. Johnson* \\ Price College of Business, University of Oklahoma, Norman, OK 73019-4006, USA \\ Lowell W. Busenitz \\ Price College of Business, University of Oklahoma, Norman, OK 73019-4006, USA
}

Received 15 March 2002; received in revised form 11 January 2003; accepted 16 January 2003

\begin{abstract}
When firms face declining financial performance, research suggests that cost and asset retrenchment can lead to improved performance among poorly performing firms. However, previous studies have largely focused on firms operating in mature industries. This research develops and tests arguments that cost and/or asset retrenchment strategies will have different effects on firm performance in competitive environments characterized as growing and declining. In growth industries, asset retrenchment was positively related to performance improvement while cost retrenchment was unrelated. In declining industries, cost retrenchment was positively related to improved performance while asset retrenchment had a negative effect on firm performance. Implications of these findings for turnaround strategies are discussed. (C) 2003 Elsevier Inc. All rights reserved.
\end{abstract}

Developing an appropriate response to a decline in firm performance is one of the most important decisions that managers must make (Ketchen \& Palmer, 1999). While restructuring strategies associated with corporate-level turnarounds have been examined extensively (see Johnson, 1996 for a review), comparatively little research has addressed business-level turnaround strategies. Perhaps the most commonly used yet understudied business-level turnaround strategy is retrenchment (Bibeault, 1982; Harrigan, 1980, 1988; Hofer, 1980; O’Neill, 1986; Robbins \& Pearce, 1992, 1994). A retrenchment strategy, the reduction of

\footnotetext{
* Corresponding author. Tel.: +1-405-325-5692; fax: +1-405-325-7688.

E-mail addresses: bmorrow@bsc.edu (J.L. Morrow Jr.), rajohnson@ou.edu (R.A. Johnson).
} 
costs and/or the elimination of assets as a means of increasing firm efficiency (Robbins \& Pearce, 1992), has been suggested as the foundation upon which firms should develop their turnaround efforts (Pearce \& Robbins, 1993; Schendel, Patton \& Riggs, 1976). Indeed, as firms struggle to respond to poor performance, announcements of plant closings (asset retrenchment) and layoffs (cost retrenchment) appear almost daily in the popular press (Carey, 2003; Shirouzu, 2002). However, while firms may frequently use a retrenchment strategy in the face of poor performance, empirical research in support of the efficacy of this strategy has generally been limited to a relatively small number of firms operating in mature industries. Thus, we explore the following research question: Do the effects of cost and asset retrenchment on firm performance vary with the nature of the firm's competitive environment?

Pearce and Robbins (1993) argued that the severity of the decline should be the primary contingency variable when deciding between cost and asset retrenchment. Our research takes a different approach by suggesting that the choice between a cost and asset retrenchment strategy should be driven in part by the nature of a firm's competitive environment and the efficiency of a firm's strategic factor markets. Under the umbrella of the product life cycle literature (Anderson \& Zeithaml, 1984; Dodge, Fullerton \& Robbins, 1994; Rink \& Swan, 1979), we employ theory from competitive dynamics (Chen, 1996; Covin, Slevin \& Covin, 1990; Gimeno, 1999; Grimm \& Smith, 1997; Zahra \& Bogner, 2000) and strategic factor markets (Barney, 1986; Dierickx \& Cool, 1989) to test the effects of cost and asset retrenchment on firms operating in growth, mature, and declining environments.

\section{The Strategy of Retrenchment}

Since the early research on retrenchment (Hambrick \& Schecter, 1983; O'Neill, 1986; Schendel et al., 1976), the emerging logic has been that cost and asset retrenchment are positively related to turnarounds and firm performance. Company and industry downturns also represent an opportunity to make needed changes in a firm (Whitney, 1987). Asset retrenchment is defined as a reduction in assets (long-term and short-term) as a means of mitigating conditions responsible for a financial downturn (Robbins \& Pearce, 1992). Specifically, plant closings, layoffs, divestitures (sell-offs, spin-offs and equity carveouts), reductions in property and equipment and inventories all fall under the strategy of asset retrenchment. Consistent with previous research (Barker \& Mone, 1994; Robbins \& Pearce, 1992) we defined cost retrenchment as a reduction in costs (e.g., selling, general and administrative expenses, cost of goods sold and interest expenses). Specifically, selling, general and administrative expenses (SGA) includes advertising expense, bad debt expense, commissions, director's fees, engineering expense, foreign currency adjustments, freight-out expense, indirect costs, lease expense, marketing expense, administrative services, pension, retirement, profit sharing, employee insurance, stock-options, R\&D, salaries, and interest expenses.

Several studies have indicated that asset and cost retrenchment should lead to performance improvements because of increased efficiencies brought about by the reduction of expenditures and the elimination of assets (DeWitt, 1998; Dodge et al., 1994; Hambrick \& Schecter, 1983; Miles, Snow \& Sharfman, 1993; O’Neill, 1986; Robbins \& Pearce, 1992). Pearce and Robbins (1993) suggested that efficiency or operating recovery strategies offer the best 
prospect for successful turnaround. They explicitly argued "that for firms facing declining financial performance, the key to a successful turnaround initially rests in the effective and efficient management of the retrenchment activities" (Pearce and Robbins, 1993: 614). In making a distinction between the retrenchment phase and the overall turnaround process, they argued that a retrenchment strategy is the first step in every turnaround process.

However, the findings and arguments of Robbins and Pearce (1992) have not gone unchallenged. In using the Robbins and Pearce (1992) sample, Barker and Mone (1994) found little evidence to support the assertion that retrenchment is an integral part of a turnaround. More explicitly, Barker and Mone argued that "Robbins and Pearce's (1992) assertion that retrenchment leads to more successful turnaround attempts disregards the growing literature on organizational downsizing suggesting that how (emphasis in the original) firms downsize or retrench is very important to the success of the process" (1994: 397). For example, Harrigan (1980, 1988) identifies two distinct motivations for retrenchment: (1) selectively shrink the business and (2) milk the investment. The former suggests the firm intends to remain in the industry while the latter suggests the firm is harvesting the assets with the intention of exiting the industry. Similarly, DeWitt (1998) argues that retrenchment may incorporate downscaling and/or downscoping activities. Downscaling refers to a reduction in the scale of operations while downscoping denotes the sale of entire business units. ${ }^{1}$ More recently, several studies have reported mixed findings for cost and asset retrenchment strategies. Michael and Robbins (1998) also found partial support for retrenchment among small firms. However, in a study of 46 distressed and recently acquired firms, Castrogiovanni and Bruton (2000) found no retrenchment effects on performance.

In sum, empirical findings have offered limited support and virtually all of this work has taken place within mature industries. This suggests that serious theoretical and empirical issues need to be addressed. In particular, the assertion that retrenchment is the critical first stage in the turnaround process may not be generalizable to poorly performing firms in all industries (Parker \& Keon, 1994; Pearce \& Robbins, 1993; Robbins \& Pearce, 1992). This research seeks to contribute to the retrenchment literature by developing stronger theoretical arguments for retrenchment activity along with testing our hypotheses using a more generalizable sample and a methodology that improves upon earlier empirical shortcomings.

\section{Competitive Environment and Retrenchment}

Given that the competitive environment can have a significant impact on member firms (Covin et al., 1990; Zahra \& Bogner, 2000), the nature of the industry environment is likely to be an important factor when considering a firm's turnaround strategy (Anderson \& Zeithaml, 1984). Firms competing in mature industries face fundamental differences from those competing in growth-oriented industries (Porter, 1980). For example, the value of firms in mature industries is largely based on the present value of anticipated cash flows (Folta, 1998). However, in growth intensive industries, value is based largely on their future growth options and their ability to discover, develop and exploit capabilities that others do not have (Kogut \& Zander, 1992). Stated differently, firms in growth industries are likely to be more concerned with exploration issues whereas firms in mature and declining industries are likely to be concerned with the exploitation of their most valuable assets. 
These arguments lead us to the position that the competitive nature of an industry will affect the direction of a firm's retrenchment strategy. Unfortunately, the retrenchment literature has not adequately considered cost and asset retrenchment within the context of different industries. Building from the recent findings that have examined cost and asset retrenchment among firms in mature industries, we suggest that insights from the competitive dynamics literature (Thomas, 1996) are useful in understanding the performance effects of a cost retrenchment strategy for firms operating in growth, mature, and declining industries. Further, because of its importance for understanding the exchange of assets, strategic factor market theory provides a useful tool for probing the effects of asset retrenchment on firm performance among firms in these same industry environments.

\section{Cost Retrenchment}

Competitive dynamics refers to a pattern of actions and responses among firms that compete within a particular industry environment (Hitt, Ireland \& Hoskisson, 2001). This competitive interaction often influences the competitive outcomes of firms' business-level strategies. Thus, the effectiveness of any strategy chosen by a firm is determined not only by the initial move, but also by anticipating and addressing the moves and countermoves of the competitors within its industry (Chen, 1996; Grimm \& Smith, 1997). Firms within an industry learn to anticipate and take into account the likely competitive responses of their industry rivals when formulating strategy (Gimeno, 1999). Researchers have suggested a wide variety of factors that firms may use to assess competitive dynamics within their industries. For example, market commonality and resource similarity (Chen, 1996) as well as market share and market dependence (Gimeno, 1999) are factors that apparently influence competitive dynamics. More central to this study, stages of industry evolution such as emerging, growth, maturity, and decline are widely recognized as having a significant influence on competitive dynamics (Folta, 1998; Grimm \& Smith, 1997; Porter, 1980).

A common thread running through this literature is that the growth rate of an industry regularly influences its competitive dynamics. For example, for firms in growth industries, dedicating resources to the development of new capabilities, innovation, market research and marketing approaches are usually critical (Dodge et al., 1994; Folta, 1998). Firms in growth industries generally have to keep developing and exploiting new product and market opportunities to fend off existing competitors and new entrants (Tegarden, Hatfield $\&$ Echols, 1999). As the viability of an emerging industry becomes increasingly apparent, competitors attempt to stake out key portions of the market (Anderson \& Zeithaml, 1984) while new entrants prospect for new opportunities and unexploited niches. All these efforts usually require substantial investments in $R \& D$, production, and marketing functions in an effort to keep pace with the industry's expansion (Herbert \& Deresky, 1987).

The above arguments have important implications for reversing the performance decline of firms in growth industries. In particular, cutting costs, and implementing strict cost controls tend to reduce the level of innovation (Hitt, Hoskisson, Johnson \& Moesel, 1996), yet firm innovation and the development of new capabilities are a central part of competition in growth industries. Indeed, the nature of competition in growth industries is such that it is widely thought that firms in this context should take an aggressive competitive posture (Grimm \& Smith, 1997; Porter, 1980). We argue that this is true even when per- 
formance suffers. To reverse declining performance, firms must often increase marketing efforts within existing markets (Baden-Fuller \& Stopford, 1994), redefine niche markets or invest resources in new technologies and innovations (Barker \& Mone, 1994; Hambrick $\&$ Schecter, 1983). This is consistent with research that recently found that when a firm's product design became antiquated, investing in and switching to the dominant design significantly increased market share and its chances of survival (Tegarden et al., 1999). If firms with declining performance cut cost while successful competitors are increasing expenditures, they are likely to fall behind in further innovative developments and lose out on customer service and markets gains (Herbert \& Deresky, 1987). Stated differently, if a firm in a growth environment engages in a cost retrenchment strategy, it is unlikely that it will be able to even maintain let alone enhance its competitive position in technological developments and market presence. Given these competitive dynamics, cost retrenchment strategies by firms in growth industries may lead to further declines in performance.

Hypothesis 1a: Cost retrenchment will have a negative effect on performance among poorly performing firms in growth industries.

Most research on firm retrenchment has occurred in industries with very modest or flat growth (Hambrick \& Schecter, 1983), commonly referred to as a stable or mature stage (Miles et al., 1993; Rink \& Swan, 1979). The transition into this phase is usually represented by fundamental changes in the firm's environment that require difficult strategic responses (Harrigan, 1988; Porter, 1980). Mature industries are often characterized by a high degree of market saturation, fewer significant product innovations, and experienced buyers who can understand and compare the product offerings of rival vendors (Harrigan, 1988). As the rate of growth slowly tapers off, overcapacity may develop. As competition intensifies, firms are generally pressured to cut costs, emphasize more efficient utilization of critical resources and limit investment in research and development (Anderson \& Zeithaml, 1984; Hambrick, MacMillan \& Day, 1982). For example, Herbert and Deresky (1987) found that firms in the mature stage of the industry life cycle followed a stabilize strategy. The focus of this strategy is to stabilize performance through cost leadership and efficiency, in part by maximizing capacity utilization and increasing standardization (Miles et al., 1993; Rink \& Swan, 1979).

Competitive dynamics within mature industries may also lead to increased price competition thereby increasing pressure to cut costs. Indeed, firms facing turnaround situations may be more inefficient than their competitors because they have not reduced their costs in the face of increasing price competition. Consistent with past research, we expect firms operating in mature industries that are facing turnaround situations to engage in cost retrenchment to increase efficiency and improve firm performance.

Hypothesis 1b: Cost retrenchment will have a positive effect on performance among poorly performing firms in mature industries.

For firms operating in declining industries, which exhibit a decline in sales over a sustained period, there are few opportunities and many threats (Miles et al., 1993). However, Harrigan $(1980,1988)$ was among the first to suggest that firms are not just limited to divestiture but they could pursue other alternatives such as "selectively shrinking the business" or "milking 
their investments." Consistent with this work, our assumption here is that single business firms primarily engage in selectively shrinking the business (Harrigan, 1980) or downscaling (DeWitt, 1998). The competitive dynamics in declining industries suggest that firms should focus on maintaining (rather than increasing) their market position (Harrigan, 1980). This suggests that firms should seek to control costs by selectively eliminating certain activities in order to stabilize profits and gain efficiencies (Dodge et al., 1994). Unlike firms in growth or even mature industries, competitive dynamics in a declining industry suggest that the ability (or need) to engage in innovations (such as investments in R\&D; production process innovations; or new marketing programs) is severely constrained (Dodge et al., 1994).

Thus, the competitive dynamics within declining industries suggest that these firms may exhibit a muddling behavior (Lawless \& Finch, 1989) in which they merely react to changing conditions due to their inability to affect the competitive environment (Dodge et al., 1994). While exit is often discussed as a strategy in declining markets, withdrawing from a market is not without difficulty. Exit barriers, such as asset-specific investments, customer service obligations, and the loss of firm recognition, often lead to high rivalry as competitors seek to utilize excess capacity (Harrigan, 1980). Because of the difficulty in disposing of assets (discussed in the next section) and the overall decline in industry profitability, managers of turnaround firms in declining industries should rely more on cost reductions to gain efficiencies and realize improved performance (Herbert \& Deresky, 1987; Parker \& Keon, 1994). This is possible in declining industries because the competitive dynamics suggest that the emphasis of most firms is on increasing efficiency by implementing strict costs controls as a means of surviving on reduced demand. Herbert and Deresky (1987) termed these actions as a harvest strategy, where the emphasis is on "winding down" the business through cost reductions.

Hypothesis 1c: Cost retrenchment will have a positive effect on performance among poorly performing firms in declining industries.

\section{Asset Retrenchment}

The second type of retrenchment that has received substantial attention in the literature is asset retrenchment (Barker \& Mone, 1994; Robbins \& Pearce, 1992). The logic with an asset retrenchment strategy is that by reducing underperforming assets, a firm can halt its downward slide and hopefully improve performance (DeWitt, 1993; Hoskisson \& Johnson, 1992). Because asset retrenchment involves the selling of assets in open markets, we utilize the theory of strategic factor markets (Barney, 1986) to develop our hypotheses. The strategic factor market concept has generally been applied to analyze the cost of developing or acquiring the resources necessary to implement a firm's product market strategies (Barney, 1986). If the strategic factor market for a given industry is perfectly competitive, the cost of a resource will approximate its economic value. Firms that utilize the markets to acquire the resources needed for implementing a given strategy will generally be unable to earn greater than a normal return from the use of those resources (Barney, 1986; Peteraf, 1993).

We propose that the strategic factor markets concept also sheds new light on understanding the impact of the sale of assets by poorly performing firms. For example, while many firms in growth industries are acquiring assets (e.g., property, plant, and equipment) to exploit 
the opportunities that are evolving in the product market, poorly performing firms are likely to sell assets that they have been unable to utilize efficiently. These assets are likely to be highly valued in the marketplace because other firms competing in growth industries are likely to need assets that can be quickly acquired and deployed in order to increase their capacity to take advantage of growth opportunities. Selling assets that are specific to a growth industry are likely to be highly valued by those seeking assets, and thus, bring a premium price in the strategic factor markets (Barney, 1986). For the retrenching firm, selling unproductive assets enables them to focus on those assets that it can utilize most efficiently. These arguments lead to the following hypothesis:

Hypothesis 2a: Asset retrenchment will have a positive effect on performance among poorly performing firms in growth industries.

Harrigan (1988) argued that a resilient resale market for a firm's assets is normally present in mature industries. DeWitt (1998) also suggested that firms in mature industries may feel pressure to increase efficiencies, which can increase economies of scale. Resources in mature industries are most valuable if they can be sold to other firms in the industry, which should lead to an active resale market for firm assets that can be readily redeployed. In a dynamic market for its factors of production, poorly performing firms in mature industries may engage in extensive asset retrenchment to decrease fixed costs associated with excess capacity and improve efficiency. Consistent with these theoretical arguments and past empirical research on asset retrenchment in mature industries (Hambrick \& Schecter, 1983; Robbins \& Pearce, 1992), firms in mature industries that engage in asset retrenchment should realize improved performance.

Hypothesis 2b: Asset retrenchment will have a positive effect on performance among poorly performing firms in mature industries.

Strategic factor markets also offer important insights for asset retrenchment in declining industries. While firms in declining industries should focus on efforts to increase efficiency (e.g., cost retrenchment), the efficacy of an asset retrenchment strategy for increasing firm performance may be hampered if the firm's resources have limited value outside the firm (DeWitt, 1998). The aforementioned problems may be exacerbated if industry demand is declining, because industry-specific assets held by a firm are unlikely to be sought by other firms either inside or outside of the industry. These industry-specific assets, by definition, will have very little value outside the industry. Furthermore, if these assets are firm-specific, they are likely to attract an even lower price in the strategic factor markets.

The concept of barriers to exit from an unattractive industry suggests that if a firm's assets are durable, firm-specific and unattractive to potential buyers, they may serve as a barrier to exit and become a source of competitive disadvantage (DeWitt, 1998). The resulting thin resale market for the assets of the business may make successful sales of these assets particularly difficult (Harrigan, 1981). Given the poor resale market for assets that are specific to a declining industry, we argue that these assets are likely to already be deployed in their highest and best use. Thus, the sale price for most of these assets is likely to be less than the discounted present value of the future cash flows that could be generated 
by the assets in their current use. The sale of such assets would likely further decrease firm performance (Donaldson, 1990). In fact, research has found that firms forced into selling assets quickly due to poor firm performance resort to "fire sales" (Donaldson, 1990). Fire sales generally result in losses from the sale of the assets and drive firm performance lower. Shleifer and Vishny (1992) found that firms operating in industries that are declining have low levels of liquidity. These low levels of liquidity require firms to offer a significant discount to sell assets quickly. They also report that assets are often sold for less than their market value. In this scenario, buyers might bid so cautiously that sellers will find it worthwhile to retain the assets (Ravenscraft \& Scherer, 1987).

Furthermore, if the sale involves firm-specific investments, profitably exiting a business in a declining industry becomes highly improbable. These assets usually have specialized and on-going functions (Dyer, 1996), which are not easy to redeploy (Kochhar, 1996). Given the nature of human-specific investments that are often linked to these assets, scale economies associated with their acquisition are likely to be very difficult to transfer (DeWitt, 1998). Therefore, the sale of highly specific assets may limit their applicability to other firms (Kochhar, 1996), thereby reducing the number of potential bidders and simultaneously lowering the potential asset resale value in the market (Sicherman \& Pettway, 1992). Because of a poor resale market due to asset specificity, problems with redeploying assets, and the short-time frame managers must operate within, we expect asset retrenchment to be negatively related to performance improvement in firms operating in declining industries.

Hypothesis 2c: Asset retrenchment will have a negative effect on performance among poorly performing firms in declining industries.

\section{Methods}

\section{Sample}

The sample for this study consisted of all single-business manufacturing firms listed on the Compustat tapes (SIC codes 2000-4000) between 1980 and 1995. Single business firms were identified using the entropy measure of diversification and the Compustat Segment Data tapes. Firms with an entropy score of zero (only one business segment) during the initial performance decline and retrenchment phase were included in the sample. The entropy measure has been widely used for such purposes and has been shown to be a valid and reliable indicator of both the level of product diversification and strategy category (cf. Chatterjee \& Blocher, 1992; Hoskisson, Hitt, Johnson \& Moesel, 1993). Diversified firms were removed because they have multiple business segments, do not report sufficient data to allow calculation of retrenchment for each business segment, and are likely to restructure through multiple divestitures when performance declines (cf. Johnson, 1996). A random sample of 1500 firms was then drawn from the population of 2,876 single-business firms operating in the industrial manufacturing segment during the time period of the study. The time period between 1980 and 1995 encompasses periods of both growth and recession, thus allowing for greater generalizability. 


\section{Turnaround Classification}

Consistent with previous studies (e.g., Barker \& Mone, 1994; Hambrick \& Schecter, 1983; Robbins \& Pearce, 1992, 1994), firms had to meet the following criteria to be included in the study: (1) The firm had to experience at least three years of declining performance (ROI) preceded by two years of successive increases in firm performance, and (2) the firm had to engage in some form of cost or asset retrenchment. ${ }^{2}$ In addition to the above criteria, the firm had to announce the use of retrenchment techniques such as cost cutting, plant closings, asset sales, employee layoffs etc. in order to be sure decreases in costs and assets were due to retrenchment. Searches of articles relating to retrenchment were conducted using Dow Jones News Retrieval, The Wall Street Journal and the popular business press. Lastly, if a firm exhibited more than one three-year period of decline we used the first period of decline in the analysis because subsequent declines may be a result of the strategies used during the initial downturn. A total of 439 firms met the requirements outlined above. Missing data reduced the sample size to 417 .

\section{Time Period}

The underlying assumption behind the model is that the effects of retrenchment take time to evolve. Previous research has tended to assume that retrenchment occurs after the year of steepest performance decline (SPD) and that retrenchment takes roughly two years to impact performance (Barker \& Mone, 1994; Robbins \& Pearce, 1992). However, corporate restructurings have been found to last for several years (Hoskisson, Johnson \& Moesel, 1994). Accordingly, data for the independent and control variables were collected for a period of six years from the onset of the initial performance decline and data for the dependent variable (performance) were collected to reflect a lag of two years relative to the independent and control variables. This six-year time period was used because it allowed sufficient time to track firms through the decline and retrenchment process as opposed to the relatively arbitrary period after the year of steepest performance decline.

\section{Industry Classification}

The 4-digit industry in which the firms compete was classified as mature, growth or decline by examining inflation adjusted sales growth over the six years starting with the initial performance decline of the firm in question. Classifying industries during each firm's turnaround period allows a more accurate classification (as opposed to assuming that industries were growing, stable or declining for the entire fifteen year period of the study). A two-stage clustering procedure was then used to identify industry clusters (cf. Hoskisson et al., 1993) based on industry growth rates. To overcome problems inherent in clustering procedures (Ketchen \& Shook, 1996), we used a combination of hierarchical and non-hierarchical clustering procedures (Milligan, 1980). The first step was to utilize a hierarchical agglomerative clustering procedure using average linkage to determine how many clusters should be used (Aldenderfer \& Blashfield, 1984). Examination of the dendogram, changes in the clustering coefficient, icicle plots, and the plot of the clustering coefficient vs. the number of clusters suggested a four-cluster solution was most appropriate. In the second 
Table 1

Results of the cluster analysis using inflation-adjusted industry sales growth rates ${ }^{\mathrm{a}}$

\begin{tabular}{lrrrrc}
\hline Cluster name & \# of 4-digit industries & \# of firms in cluster & Mean & S.D. & Range \\
\hline Growth & 15 & 61 & 13.27 & 5.09 & $10.22-17.72$ \\
Mature & 111 & 253 & 3.50 & 2.84 & $.01-9.15$ \\
Decline & 47 & 98 & -3.88 & 2.56 & -12.55 to -.83 \\
Hyper-growth & 5 & 5 & 33.41 & 5.65 & $21.83-38.62$ \\
\hline
\end{tabular}

$N=178,4$-digit SIC codes or different industries.

${ }^{a}$ Pooled for reporting purposes.

step, we used a non-hierarchical clustering procedure based on the seed points identified in the hierarchical procedure and a four-cluster solution (Hair, Anderson, Tatham \& Black, 1992).

Results using a combination of these two clustering procedures suggested a four-cluster solution, which is presented in Table 1 . The four clusters were labeled hyper-growth, growth, mature and decline. The five firms that were classified as operating in hyper-growth industries were removed from subsequent analysis due to the small number of firms in this industry category. Of the 412 firms in the final sample, 253 were classified as operating in mature industries, 98 in declining industries and 61 in growth industries.

The industry classifications derived from cluster analysis are very similar to those reported by Miles et al. (1993). Miles and his colleagues used industry sales data from U.S. Industrial Outlook and classified mature industries as those 4-digit SIC codes experiencing 1-10 percent growth, growth industries as those 4-digit SIC codes with greater than 10 percent sales growth and declining industries as those 4-digit SIC codes with negative sales growth.

\section{Measures}

Dependent variable. The dependent variable in most previous retrenchment research has been operationalized as the change in return on investment (ROI) from one period to the next. This approach has been criticized because it does not measure the actual level of performance achieved by retrenching firms (Barker \& Mone, 1994). In other words, by looking only at a change in ROI, firms could improve their performance but still be performing poorly. In this study, we used industry adjusted return on investment (ROI). Industry adjusted ROI was operationalized as firm ROI minus industry average ROI at the 4-digit SIC code level (Hoskisson et al., 1994) for each of the six years examined. In addition to controlling for industry effects, research by Meindl, Ehrlich and Dukerich (1985) suggests that managers as well as board members compare firm performance to average industry performance when evaluating strategies and the need for change. Thus, declines in performance relative to industry averages may be an important indicator of the need for action and the effectiveness of retrenchment.

This study also utilized two additional measures of performance: Tobin's $Q$ and the market-to-book ratio. Based on previous research (Chung \& Pruitt, 1994; Thomas \& Waring, 1999) we operationalized Tobin's $Q$ as the sum of the market value of equity, the book value of debt, and deferred taxes divided by the book value of total assets minus intangible assets. 
Tobin's $Q$ measures the ratio of the market value of a company's debt and equity to the replacement cost of its assets. The market-to-book ratio is operationalized as the fiscal year-end stock price divided by the book value per share. For our purposes, book value per share is equal to common shareholder equity divided by common shares outstanding. Both of these measures compare the market value of the firm with its corresponding book value. These types of measures are an appropriate indicator of the perceived ability of the firm's strategy to achieve the required returns of investors (Woo, Willard \& Daellenbach, 1992). As above, these data were calculated yearly for the six years used in the study.

Independent variables. Two independent variables were used in the study: (1) cost retrenchment and (2) asset retrenchment. Consistent with previous research (Barker \& Mone, 1994; Robbins \& Pearce, 1992), the firm's cost base was calculated yearly as selling, general and administrative expenses plus interest expenses (where selling, general and administrative expense is equal to sales minus cost of goods sold minus operating income) during the six years starting with the initial performance downturn. Cost retrenchment (change in the firm's cost base) was then calculated through orthonormalized contrasts during the repeated measures analysis. The firm's asset base was calculated yearly as the sum of cash and cash equivalents, accounts receivable, inventories and gross property, plant, and equipment (Robbins \& Pearce, 1992) for each of the six years starting with the initial performance downturn. As above, asset retrenchment (change in the firm's asset base) was calculated during the repeated measures regression analysis through the use of contrasts.

Control variables. We controlled for four different factors that may lead to changes in firm performance during turnaround situations: (1) firm size, (2) firm slack, (3) firm current ratio and (4) the severity of performance decline. Firm size has been shown to affect the ability of managers to make necessary changes in the face of environmental threats (Tushman \& Romanelli, 1985). Firm size was operationalized as the log of total firm employees. Previous research suggests that the level of firm slack may affect the likelihood of a successful turnaround (Hambrick \& D'Aveni, 1988). The firm's equity-to-debt ratio was used to operationalize firm slack. The equity-to-debt ratio represents the unused borrowing capacity available to the firm and is analogous to the concept of unabsorbed slack or excess uncommitted resources (Singh, 1986). Firm current ratio (current assets/current liabilities) was used to control for the availability of liquid or nearly liquid resources to cover short-term obligations. Lastly, previous research (Bibeault, 1982; Hofer, 1980) has suggested that the severity of the performance decline may influence the type of retrenchment strategies used. Specifically, the more severe the performance decline, the more likely asset retrenchment will be used. We therefore used a dummy variable coded as " 0 " if the firm is performing above the industry average during a given year of the retrenchment effort and " 1 " if the firm was performing below the industry average during any given year. All control variables were computed for each of the six years starting with the initial performance downturn.

Analysis

Repeated measures regression analysis was used to test the hypotheses. As noted by Bergh (1995), repeated measures analysis transforms the repeated measures of each variable into 
Table 2

Means, standard deviations, and intercorrelations for variables used in the study ${ }^{\mathrm{a}, \mathrm{b}, \mathrm{c}}$

\begin{tabular}{lrrrrrrrrr}
\hline Variables & Means & \multicolumn{1}{c}{ S.D. } & \multicolumn{1}{c}{1} & 2 & 3 & 4 & 5 & 6 & 7 \\
\hline 1. Industry adjusted ROI & -1.86 & 7.06 & & & & & & & \\
2. Tobin's $Q$ & 1.26 & 14.06 & .08 & & & & & \\
3. Cost base & 65.63 & 221.46 & -.09 & .02 & & & & \\
4. Asset base & 373.86 & 1187.92 & -.13 & .03 & .26 & & & \\
5. Firm size & 2.59 & 1.61 & -.11 & -.06 & -.01 & .24 & & & \\
6. Firm slack & 12.24 & 16.29 & .12 & .05 & .03 & .10 & -.11 & & \\
7. Current ratio & 2.21 & 2.78 & .13 & .01 & -.03 & .11 & .05 & .03 & \\
8. Severity & .43 & .12 & -.27 & -.09 & -.12 & .03 & .09 & -.20 & -.38
\end{tabular}

$N=2,472$ (412 cases multiplied by six years).

a Values are pooled for reporting purposes.

${ }^{\mathrm{b}}$ Correlations greater than .05 are significant at the $p<.05$ level.

${ }^{\mathrm{c}}$ Correlations reported reflect the correlations of the principal components of the variables and not the change calculated through orthonormalized contrasts.

${ }^{\mathrm{d}}$ Spearman rank correlations are reported where ordinal data is used.

orthonormalized contrasts and then tests whether the contrasts are related to each other. This procedure overcomes problems associated with change scores and serial autocorrelation. Hypothesis testing involved regressing changes in firm performance on changes in cost and asset retrenchment for each industry category.

\section{Results}

Table 2 reports means, standard deviations and correlations for the dependent, independent, and control variables used in the study. As Table 2 indicates, intercorrelations among independent variables were generally low thereby minimizing the problem of unstable coefficients in the linear regression models. Of the 412 firms in the final sample, 237 firms engaged in both cost and asset retrenchment, 107 engaged in asset retrenchment only, and 68 firms engaged in cost retrenchment only. The average percentage of cost and asset retrenchment in growth industries was 3.42 and 6.49 percent, respectively, in mature industries 7.84 and 3.61 percent and in declining industries 4.61 and 4.05 percent, respectively. Results of a Bonferroni multiple comparison indicates that the percentage of asset retrenchment is significantly larger in growth industries as opposed to declining industries $(t=2.51$, $p<.05)$. Furthermore, the percentage of cost retrenchment is significantly larger in declining industries than it is in growth industries $(t=2.15, p<.05)$. Lastly, a Bonferroni test indicated that significant differences existed across the three industry categories with respect to the total decline in performance. Subsequent $t$-tests indicate that firms in growth industries exhibited significantly smaller declines in performance than firms operating in declining industries $(t=2.46, p<.05)$.

Results of the hypotheses tests are presented in Table 3. A total of three different models were estimated: (1) growth industries (model 1), (2) mature industries (model 2) and (3) declining industries (model 3). Two repeated measures regressions were estimated within each model to allow an examination of the effect of retrenchment on both accounting-based 
Table 3

Results of the repeated measures regression analysis

\begin{tabular}{|c|c|c|c|c|c|c|}
\hline & \multicolumn{2}{|l|}{ Model 1} & \multicolumn{2}{|l|}{ Model 2} & \multicolumn{2}{|l|}{ Model 3} \\
\hline & \multicolumn{2}{|c|}{ Growth industry } & \multicolumn{2}{|c|}{ Mature industry } & \multicolumn{2}{|c|}{ Declining industry } \\
\hline & ROI & Tobin's $Q$ & ROI & Tobin's $Q$ & ROI & Tobin's $Q$ \\
\hline \multirow{2}{*}{\multicolumn{7}{|c|}{$\begin{array}{l}\text { Dependent variable } \\
\text { Control variables }\end{array}$}} \\
\hline & & & & & & \\
\hline Firm size & $-.22 *$ & $-.19^{\dagger}$ & $-.27^{* *}$ & $-.23^{*}$ & -.12 & $-.18^{\dagger}$ \\
\hline Firm slack & .17 & .13 & $.21^{\dagger}$ & .11 & $.19^{\dagger}$ & .09 \\
\hline Current ratio & $.31^{* *}$ & $.24^{*}$ & $.20^{\dagger}$ & $.22^{*}$ & .10 & $.19^{\dagger}$ \\
\hline Severity & -.15 & $-.18^{\dagger}$ & $-.24^{* *}$ & $-.25^{* *}$ & $-.36^{* * *}$ & $-.23^{*}$ \\
\hline \multicolumn{7}{|l|}{ Independent variables } \\
\hline Cost retrenchment & -.11 & .01 & $.23^{*}$ & $.20^{*}$ & $.33^{* *}$ & .13 \\
\hline Asset retrenchment & $.30^{* *}$ & $.26^{* *}$ & $.32^{* *}$ & $.28^{* *}$ & $-.22^{*}$ & -.02 \\
\hline Wilk's lambda & .83 & .85 & .77 & .79 & .80 & .89 \\
\hline$F$-statistic & $2.60^{* *}$ & $2.57^{* *}$ & $3.23^{* * *}$ & $3.13^{* * *}$ & $2.66^{* *}$ & $2.20^{*}$ \\
\hline$N($ firms $\times 6$ years $)$ & 366 & 366 & 1518 & 1518 & 588 & 588 \\
\hline $\begin{array}{l}\dagger p<.10 \\
{ }^{\dagger} p<.05 \\
{ }^{* *} p<.01 \\
{ }^{* * *} p<.001\end{array}$ & & & & & & \\
\hline
\end{tabular}

and market-based performance measures. Results of the Mauchly's $W$ tests for the presence of variance homogeneity between repeated measures in each model were significant thereby indicating symmetry conditions were violated and the variances were significantly different (see Bergh, 1995). We used an epsilon modification process (Bergh, 1995) to adjust the degrees of freedom based on Greenhouse-Geisser epsilon values.

Test results for the growth industry hypotheses are presented in Model 1. Hypothesis 1a was not supported. Cost retrenchment was negatively but not significantly related to changes in ROI in growth industries. Similarly, cost retrenchment was not significantly related to changes in Tobin's $Q$ in growth industries. However, asset retrenchment was positively and significantly related to performance in growth industries using both ROI and Tobin's $Q$, which supports Hypothesis $2 \mathrm{a}$.

Results of the mature industry hypotheses are presented in Model 2. Hypothesis 1b predicted that cost retrenchment would have a positive effect on firm performance in mature industries. Results suggest support for Hypothesis $1 \mathrm{~b}$ in that cost retrenchment has a positive impact on both accounting (ROI) and market-based (Tobin's $Q$ ) performance. Similarly, Hypothesis $2 \mathrm{~b}$ suggested asset retrenchment would be positively related to firm performance in mature industries. As above, asset retrenchment was positively related to both accounting and market-based performance thereby providing support for Hypothesis $2 b$.

Model 3 presents hypotheses tests for declining industries. Cost retrenchment was positively and significantly related to performance improvement. However, cost retrenchment was unrelated to Tobin's $Q$. Therefore, Hypothesis 1c received support with respect to accounting performance but not market-based performance. Asset retrenchment was nega- 
tively and significantly related to performance when ROI was used but was unrelated when Tobin's $Q$ was used as the dependent variable. Thus, Hypothesis 2c was supported with respect to accounting performance but not market performance.

We also tested all three sets of industries using the market to book measures of performance. However, the results are virtually identical to the reported results using Tobin's $Q$. Upon further analysis, we found Tobin's $Q$ and market to book measures of performance to be highly correlated $(r=.83)$. In light of this high correlation and given that previous research has used market to book ratios as a proxy for Tobin's $Q$, we opted to use Tobin's $Q$ as our market-based measure of performance.

Lastly, several of the control variables were consistently significant. Firm size was consistently negatively related to firm performance using both accounting and market measures. Slack was consistently positive but was not significantly related to performance in growth industries or when market measures of performance were used. The current ratio was also consistently positive. The severity of performance decline was consistently significant and negatively related to firm performance although this relationship was not significant in growth industries.

\section{Discussion}

Despite being a very popular turnaround strategy among practicing managers, retrenchment has been an understudied topic in the strategic management literature. Indeed, much of the systematic research on cost and asset retrenchment was based solely on firms operating in mature industries (Hambrick \& Schecter, 1983; Robbins \& Pearce, 1992). These studies, and the widespread use of retrenchment by practitioners, have lead some to suggest that the benefits from retrenchment may be generalized to all firms (e.g., Pearce \& Robbins, 1993). Barker and Mone (1994) were among the first to question the generalizability of a retrenchment strategy, and they also criticized previous retrenchment research on methodological grounds. This study sought to address these issues by separately examining the effects of cost and asset retrenchment in different competitive environments (growth, mature and decline). We also improved on prior research by only including firms in the sample that had actually announced a retrenchment strategy and by using a repeated measures design, which can overcome concerns that have been expressed regarding the use of change scores and serial autocorrelation in past research.

Prior studies had found that poorly performing firms operating in mature industries realized improved performance after implementing a cost and/or asset retrenchment strategy (Hambrick \& Schecter, 1983; Robbins \& Pearce, 1992, 1994). Our research validated these studies using a sample of 253 firms representing 111 four-digit industries. Furthermore, both cost and asset retrenchment had a positive impact on our market-based measures of performance (Tobins' $Q$ and the market-to-book ratio). These findings are important because they provide evidence that the performance effects of retrenchment strategies can be generalized beyond the textile industry across multiple mature industries and to both market-based and accounting-based performance. Thus, mounting empirical evidence supports the theoretical arguments that when performance suffers, firms operating in mature industries should reduce unnecessary costs and assets as a means 
of increasing short-term performance and positioning the firm for a return to normal growth.

Strategy research has long argued that the nature of a firm's competitive environment is an important factor in strategy formulation (DeWitt, 1998; Folta, 1998; Gimeno, 1999; Zahra \& Bogner, 2000). The findings of this study provide substantial support suggesting that firms should tailor their retrenchment strategy according to the nature of their competitive environments. Specifically, firms operating in declining competitive environments should focus their retrenchment efforts on moves to gain efficiencies by reducing costs. Efforts by firms in declining environments to increase their performance by reducing their asset base appear to have a negative effect on firm performance, presumably because of the very thin resale market for assets that are specific to an industry that is in decline (DeWitt, 1998). The lack of a relationship between cost and asset retrenchment on Tobin's $Q$ suggests that these strategies may not be as viable in declining industries as they are in mature industries. In order to examine these findings further we conducted an event study to examine the impact of the announcement of retrenchment on firm returns. We measured stock market return using the standard event study methodology, whereby a Cumulative Abnormal Return (CAR) was computed for the days surrounding the restructuring announcement. The standard event study approach estimates a market model for each firm and then calculates a cumulative abnormal return for the event. Specifically, the CARs were estimated using the following equation:

$$
\mathrm{AR}_{i t}=R_{i t}-\left(a_{i}+b_{i} R_{m t}\right)
$$

where $a_{i}$ and $b_{i}$ are the ordinary least squares (OLS) parameter estimates obtained for the regression of $R_{i t}$ on $R_{m t}$ over an estimation period $(T)$ preceding the event; $\mathrm{AR}_{i t}$ is daily abnormal returns, $R_{i t}$ is the rate of return on the share price of firm $i$ on day $t$ and $R_{m t}$ is the rate of return on the $\mathrm{S} \& \mathrm{P} 500$ on day $t$. The parameter estimates were based on an estimation period of 250 days ( -300 to -50 ) before the retrenchment announcement. Abnormal returns were cumulated over the 2-day window surrounding the announcement date. This particular window length is recommended, as opposed to a longer one, as it lowers the probability of bias from confounding events (McWilliams \& Siegel, 1997). Unfortunately, roughly $60 \%$ of our firms used both cost and asset retrenchment in their turnaround effort. This reduced the number of firms using either cost or asset retrenchment to levels within each industry group that did not allow individual assessments of announcement effects. We therefore examined the announcement effect for retrenchment strategies for each industry group. Results of this analysis indicate that the announcement of retrenchment in declining industries resulted in a gain of .4 percent but this change was not significantly different from market average. Conversely, CARs to firms announcing retrenchment in growth industries were positive and significant $(1.6$ percent, $t=2.20, p<.05)$ as were CARs surrounding the announcement of retrenchment in mature industries $(1.34$ percent, $t=2.01, p<.05)$. Combining the results of the event study with the non-significant findings using Tobin's $Q$ and market to book measures for firms in declining industries suggests market expectations with respect to the future expected value of firm assets are low. It may be that the market anticipated the announcement of cost retrenchment in these declining industries and given the declining nature of the industry, firm assets are discounted by the market. Thus while cost retrenchment in a declining industry improves accounting performance (a short-run 
measure), market-based measures which estimate the future expected value of the assets (a longer-term measure) are not so affected. This result suggests that tactical moves associated with cost-cutting are not viewed by the market as a strategic change that is designed to alter firm strategy.

On the other hand, for firms operating in growth industries, retrenchment efforts that focus on reducing assets resulted in improved performance, arguably because of a very competitive resale market for these assets. However, Hypothesis 1a, which was not supported, predicted a negative relationship between cost retrenchment and performance improvement in growth industries. Results suggest that cost retrenchment is unrelated to performance change in growth industries. We suspect that the lack of support for this hypothesis indicates that firms in growth industries may not engage in extensive cost retrenchment because doing so may hinder the firm's future competitive prospects. We used an ANOVA model to examine whether the degree of cost retrenchment differed across industry categories. Results indicate that significant differences are present $(F=5.37, p<.005)$. A Bonferroni multiple comparison of the means across industries indicated that the degree of cost retrenchment in growth industries was significantly less than the degree of cost retrenchment in declining industries at the $p<.05$ level. Thus, managers of firms operating in growth industries may not find cost retrenchment strategies desirable. Another explanation may be that the firms cut costs in areas that do not affect the viability of the firm (e.g., non-critical expenditures). For example, due to the nature of the industry, turnaround firms in growth industries may not cut R\&D expenses. In fact, while firms in the combined sample significantly reduced $\mathrm{R} \& \mathrm{D}$ intensity during cost retrenchment $(t=2.36, p=.02)$, turnaround firms in growth industries did not cut $\mathrm{R} \& \mathrm{D}$ intensity significantly $(t=1.36, p=.17)$. Further examination of the results indicates that when firms in growth industries reduced R\&D intensity they reduced this expenditure down to industry average levels.

Both asset and cost retrenchment are popular strategies among practitioners because they are widely viewed as leading to an improvement in firm performance. This research challenges this view with a new perspective that suggests managers of firms in growing and declining industry environments should be cautious about the type of retrenchment strategy they choose. Managers face immense pressure to turnaround poorly performing firms and retrenchment appears to offer many managers the prospect of a "quick fix." However, this research provides a broader viewpoint that suggests strategy formulation that is contingent on the nature of the firm's competitive environment may be critical for turnaround success.

It has been suggested that the turnaround process consists of two distinct stages (Hambrick \& Schecter, 1983; Hofer, 1980; Pearce \& Robbins, 1993), sometimes described as "stop the bleeding" and "return to growth or recovery." This research addresses the first of these two stages. Whether cost and/or asset retrenchment strengthens a firm's position for the second stage (or whether a second stage actually exists) is a question for future research. In particular, if a firm eliminates valuable strategic resources during the retrenchment phase, its ability to thrive (or even survive) in a second phase may be in doubt. While selling off assets, even at a premium price, may generate cash in the short run, such actions could stifle the firm's ability to position itself for successfully competing in the long run. On the other hand, if the assets that were sold were unnecessary or perhaps burdensome in light of the firm's future strategy, then the elimination of these assets may enhance the firm's long term prospects. Similar arguments can also be made on the cost retrenchment side. 
Whether reducing costs to realize improved performance in the short run helps or hurts future performance depends in part on what type of costs were reduced, the size of these reductions and the strategy that a firm chooses to pursue in the future.

\section{Conclusion}

Understanding the strategies that lead to improved performance among poorly performing firms has important implications for both scholars and practicing managers. Robbins and Pearce (1994) contend that retrenchment serves as the foundation for turnaround success. Our research generally supports this assertion but offers an important qualification to the notion that both cost and asset retrenchment are appropriate turnaround strategies regardless of the nature of the firm's competitive environment. Practitioners in growth and declining industries should carefully consider their options when choosing between cost and asset retrenchment.

\section{Notes}

1. DeWitt's (1998) arguments are based on large diversified firms (the largest 21 firms that were publicly traded between 1957 and 1987). In this context, both downscaling and downscoping are feasible. With single business firms, the option of downscoping is not feasible, short of going out of business. Thus, DeWitt's downscaling category is appropriate for single business firms. Similarly, Harrigan presents two options: (1) selectively shrinking the business and (2) milking the investment. For single business firms, harvesting strategies are problematic given that the firm operates in only one industry. Therefore, selectively shrinking the business is more likely.

2. Examinations of the SIC industry codes for firms in our sample over the time period of the study suggests that firms did not move to different industries nor did they sell off entire units such that their SIC codes changed. This lack of change provides support for our assertion that the goal of the retrenchment strategy in single-business firms is to selectively shrink the business and/or downscale operations.

\section{Acknowledgments}

We would like to thank Mike Hitt and Bob Hoskisson for helpful comments on an earlier draft of this paper. We also thank Don Bergh for his helpful comments and suggestions with the repeated measures analysis used in this study.

\section{References}

Aldenderfer, M. S., \& Blashfield, R. K. 1984. Cluster analysis. Beverly Hills, CA: Sage.

Anderson, C. R., \& Zeithaml, C. P. 1984. Stage of the product life cycle, business strategy, and business performance. Academy of Management Journal, 27: 5-24. 
Baden-Fuller, C., \& Stopford, J. M. 1994. Rejuvenating the mature business. Boston: Harvard Business School Press.

Barker, V. L., III, \& Mone, M. A. 1994. Retrenchment: Cause of turnaround or consequence of decline? Strategic Management Journal, 15: 395-405.

Barney, J. B. 1986. Strategic factor markets: Expectations, luck, and business strategy. Management Science, 42 : 1231-1241.

Bergh, D. D. 1995. Problems with repeated measures analysis: Demonstration with a study of the diversification and performance relationship. Academy of Management Journal, 38: 1692-1708.

Bibeault, D. G. 1982. Corporate turnaround: How managers turn losers into winners. New York: McGraw-Hill.

Carey, S. 2003. As part of cost-cutting scheme, United to eliminate 1,500 jobs. Wall Street Journal, January 5.

Castrogiovanni, G. J., \& Bruton, G. D. 2000. Business turnaround processes following acquisitions: Reconsidering the role of retrenchment. Journal of Business Research, 48: 25-34.

Chatterjee, S., \& Blocher, J. D. 1992. Measurement of firm diversification: Is it robust? Academy of Management Journal, 35: 874-888.

Chen, M. 1996. Competitor analysis and interfirm rivalry: Toward a theoretical integration. Academy of Management Review, 21: 100-134.

Chung, K. H., \& Pruitt, S. W. 1994. A simple approximation of Tobin's Q. Financial Management, 23(3): 70-74.

Covin, J. G., Slevin, D. P., \& Covin, T. J. 1990. Content and performance of growth-seeking strategies: A comparison of small firms in high- and low-technology industries. Journal of Business Venturing, 5: 391412.

DeWitt, R. L. 1993. The structural consequences of downsizing. Organization Science, 4(1): 30-40.

DeWitt, R. L. 1998. Firm, industry, and strategy influences on choice of downsizing approach. Strategic Management Journal, 19: 59-79.

Dierickx, I., \& Cool, K. 1989. Asset stock accumulation and sustainability of competitive advantage. Management Science, 35: 1504-1511.

Dodge, H. R., Fullerton, S., \& Robbins, J. E. 1994. Stage of the organizational life cycle and competition as mediators of problem perception in small businesses. Strategic Management Journal, 15: 121-134.

Donaldson, G. 1990. Voluntary restructuring: The case of General Mills. Journal of Financial Economics, 27 : 117-141.

Dyer, J. H. 1996. Specialized supplier networks as a source of competitive advantage: Evidence from the auto industry. Strategic Management Journal, 17: 271-291.

Folta, T. 1998. Governance and uncertainty: The trade-off between administrative control and commitment. Strategic Management Journal, 19: 1007-1028.

Gimeno, J. 1999. Reciprocal threats in multimarket rivalry: Staking out 'spheres of influence' in the U.S. airline industry. Strategic Management Journal, 20: 101-128.

Grimm, C. M., \& Smith, K. G. 1997. Strategy as action: Industry rivalry and coordination. West Publishing: St. Paul, MN.

Hair, J. F., Anderson, R. E., Tatham, R. L., \& Black, W. C. 1992. Multivariate data analysis. MacMillan: New York.

Hambrick, D. C., \& D’Aveni, R. A. 1988. Large corporate failures as downward spirals. Administrative Science Quarterly, 33: 1-23.

Hambrick, D. C., McMillan, I. C., \& Day, D. L. 1982. Strategic attributes and performance in the BCG matrix-A PIMS-based analysis of industrial product businesses. Academy of Management Journal, 25: 510-531.

Hambrick, D. C., \& Schecter, S. 1983. Turnaround strategies in mature industrial product business units. Academy of Management Journal, 26: 231-248.

Harrigan, K. R. 1980. Strategies for declining businesses. Lexington, MA: Lexington Books.

Harrigan, K. R. 1981. Deterrents to divestiture. Academy of Management Journal, 24: 306-323.

Harrigan, K. R. 1988. Managing maturing businesses. Lexington, MA: Lexington Books.

Herbert, T. T., \& Deresky, H. 1987. Generic strategies: An empirical investigation of typology validity and strategy content. Strategic Management Journal, 8: 135-147.

Hitt, M. A., Hoskisson, R. E., Johnson, R. A., \& Moesel, D. D. 1996. The market for corporate control and firm innovation. Academy of Management Journal, 39: 1084-1119.

Hitt, M. A., Ireland, R. D., \& Hoskisson, R. E. 2001. Strategic management: Competitiveness and globalization (4th ed.). Cincinnati, OH: South-Western College Publishing. 
Hofer, C. W. 1980. Turnaround strategies. Journal of Business Strategy, 1: 19-31.

Hoskisson, R. E., Hitt, M. A., Johnson, R. A., \& Moesel, D. D. 1993. Construct validity of an objective (entropy) categorical measure of diversification strategy. Strategic Management Journal, 14: 215-235.

Hoskisson, R. E., \& Johnson, R. A. 1992. Corporate restructuring and strategic change: The effect on diversification strategy and R\&D intensity. Strategic Management Journal, 13: 625-634.

Hoskisson, R. E., Johnson, R. A., \& Moesel, D. D. 1994. Corporate divestiture intensity in restructuring firms: Effects of governance strategy and performance. Academy of Management Journal, 37: 1207-1251.

Johnson, R. A. 1996. Antecedents and outcomes of corporate refocusing. Journal of Management, 22: 437-481.

Ketchen, D. J., Jr., \& Palmer, T. B. 1999. Strategic responses to poor organizational performance: A test of competing perspectives. Journal of Management, 25: 683-706.

Ketchen, D. J., Jr., \& Shook, C. L. 1996. The application of cluster analysis in strategic management research: An analysis and critique. Strategic Management Journal, 17: 441-458.

Kochhar, R. 1996. Explaining firm capital structure: The role of agency theory vs. transaction cost economics. Strategic Management Journal, 17: 713-728.

Kogut, B., \& Zander, U. 1992. Knowledge of the firm, combinative capabilities, and the replication of technology. Organization Science, 3: 383-397.

Lawless, M. W., \& Finch, L. K. 1989. Choice and determinism: A test of Hrebiniak and Joyce's framework on strategy environment fit. Strategic Management Journal, 10: 315-365.

McWilliams, A., \& Siegel, D. 1997. Event studies in management research: Theoretical and empirical issues. Academy of Management Journal, 40: 626-657.

Meindl, J. R., Ehrlich, S. B., \& Dukerich, J. M. 1985. The romance of leadership. Administrative Science Quarterly, 30: 78-102.

Michael, S. C., \& Robbins, D. K. 1998. Retrenchment among small manufacturing firms during recession. Journal of Small Business Management, 36(3): 35-45.

Miles, G., Snow, C. C., \& Sharfman, M. P. 1993. Industry variety and performance. Strategic Management Journal, 14(3): 163-177.

Milligan, G. 1980. An examination of the effect of six types of error perturbation on fifteen clustering algorithms. Psychometrica, 45: 325-342.

O’Neill, H. M. 1986. Turnaround and recovery: What strategy do you need? Long Range Planning, 19: 80-88.

Parker, B., \& Keon, T. L. 1994. Coping with industrial decline: A test of generic strategies used by small firms. Journal of Business and Entrepreneurship, 6: 11-21.

Pearce, J. A., \& Robbins, D. K. 1993. Toward improved theory and research on business turnaround. Journal of Management, 19: 613-636.

Peteraf, M. A. 1993. The cornerstones of competitive advantage: A resource-based view'. Strategic Management Journal, 14: 179-191.

Porter, M. E. 1980. Competitive strategy. New York: Free Press.

Ravenscraft, D. J., \& Scherer, F. M. 1987. Mergers, sell-offs, and economic efficiency. Washington, DC: The Brookings Institution.

Rink, D. R., \& Swan, J. E. 1979. Product life cycle research: A literature review. Journal of Business Research, 7 : 219-242.

Robbins, D. K., \& Pearce, J. A. 1992. Turnaround: Retrenchment and recovery. Strategic Management Journal, 13: 287-309.

Robbins, D. K., \& Pearce, J. A. 1994. Retrenchment remains the foundation of business turnaround. Strategic Management Journal, 15: 407-417.

Schendel, D., Patton, G. R., \& Riggs, J. 1976. Corporate turnaround strategies: A study of profit decline and recovery. Journal of General Management, 3(Spring): 3-11.

Shirouzu, N. 2002. Big three's plant shutdowns to test tentative peace with labor unions. Wall Street Journal, February 25.

Shleifer, A., \& Vishny, R. 1992. Liquidation values and debt capacity: A market equilibrium approach. Journal of Finance, 47: 1343-1366.

Sicherman, N. W., \& Pettway, R. H. 1992. Wealth effects for buyers and sellers of the same divested assets. Financial Management, 21: 119-128.

Singh, J. V. 1986. Performance, slack, and risk taking in organizational decision making. Academy of Management Journal, 29: 562-585. 
Tegarden, L. F., Hatfield, D. E., \& Echols, A. E. 1999. Doomed from the start: What is the value of selecting a future dominant design? Strategic Management Journal, 20: 495-518.

Thomas, L. G. 1996. The two faces of competition: Dynamic resourcefulness and the hypercompetitive shift. Organization Science, 7: 221-242.

Thomas, L. G., \& Waring, G. 1999. Competing capitalisms: Capital investment in American, German, and Japanese firms. Strategic Management Journal, 20: 729-748.

Tushman, M., \& Romanelli, E. 1985. Organizational evolution: A metamorphosis model of convergence and reorientation. In L. L. Cummings \& B. M. Staw (Eds.), Research in organizational behavior (Vol. 7: 171-222). Greenwich, CT: JAI Press.

Woo, C. Y., Willard, G. E., \& Daellenbach, U. S. 1992. Spin-off performance: A case of overstated expectations? Strategic Management Journal, 13: 433-447.

Whitney, J. O. 1987. Taking charge: Management guide to troubled companies and turnarounds. Homewood, IL: Dow Jones-Irwin, Inc.

Zahra, S. A., \& Bogner, W. C. 2000. Technology strategy and software new ventures' performance: Exploring the moderating effect of the competitive environment. Journal of Business Venturing, 15: 135-173.

J.L. Morrow Jr. is an assistant professor of business administration in the Division of Business and Graduate Programs at Birmingham-Southern College. He received his Ph.D. in business administration with a major in management from Texas A\&M University. His research focuses on the relationship between socially complex resources and competitive advantage. He is particularly interested in how these resources affect the performance of strategic alliances and organizations facing the need for strategic change.

Richard A. Johnson holds the Puterbaugh Chair in American Enterprise at the Michael F. Price College of Business at the University of Oklahoma. He received his Ph.D. in strategic management from Texas A\&M University. His current research interests include corporate restructuring, corporate governance and controls, international diversification, and corporate innovation.

Lowell Busenitz is an associate professor of management at the Price College of Business, University of Oklahoma. He received his Ph.D. in strategic management from Texas A\&M University. His research interests include resource-based theory, entrepreneurial decision-making, and venture capitalist involvement in entrepreneurial firms. 